\section{ISLAMIC BANK AND SHARIA BUSINESS UNIT IN INDONESIA: A COMPARISON ON INTELLECTUAL CAPITAL DISCLOSURE PRATICES}

\author{
Ihyaul Ulum ${ }^{1}$, Ismi' Nor Amdini², \\ Setu Setyawan ${ }^{3}$, Nafsiah Mohamed ${ }^{4}$ \\ ${ }^{123}$ Accounting Department, University of Muhammadiyah Malang \\ Jl. Raya Tlogomas No.246 Malang, Indonesia \\ ${ }^{4}$ Accounting Research Institute (ARI) UiTM Malaysia, \\ 40450 Shah Alam, Selangor Darul Ehsan Malaysia \\ ${ }^{1 \cdot C o r r e s p o n d i n g ~ a u t h o r: i h y a u l @ u m m . ~ a c . i d ~}$
}

JRAK

diterima 26 Maret 2018, direview 26 Maret 2018, direvisi 28 Maret 2018, diterima 29 Maret 2018 .

Artikel ini tersedia di website: http:// ejournal.umm.ac.id/ index.php/jrak

Doi: 10.22219 / jrak.v8i1.22

\begin{abstract}
This study aims to compare the intellectual capital disclosures (ICD) in annual reports between Islamic Banks and Sharia Business Unit in 2015. Intellectual capital (ICD) is divided into three main components namely; Human capital, Structural capital and relational capital. The components used in this study is the ICD-In framework written by Ulum (2015) which consists of 36 items of intellectual capital. This study uses purposive sampling to determine the sample of Islamic bank and Sharia business units registered in Bank Indonesia in 2015, with a sample of 34 banks. The results indicate that there was a difference practices on intellectual capital disclosures of Islamic banks and Sharia business unit. Islamic banks disclosed on IC higher than Sharia business unit.
\end{abstract}

Keywords: Intellectual capital Disclosure, Islamic Banks, Sharia Business Unit.

\section{INTRODUCTION}

Over the last few decades, research on the intellectual capital disclosure has attracted the attention of researchers because it contains intangible assets used to enhance shareholder value. Besides the intellectual capital disclosure is also considered as necessary by the company management to meet the needs of information users, so the information asymmetry between the two can be minimized. The information disclosed in the annual report of an entity can be classified into two, namely the mandatory disclosure and voluntary disclosure (Nuswandari, 2009).

Reporting of intellectual capital (IC) is one element of a voluntary reporting. Although not included the fundamental reports in an annual report, but the voluntarily report is sufficiently representative in answering the needs of the wider information for annual reports users (Ulum et al., 2016a). In Indonesia, implicitly IC has been recognized and addressed in the Statement of Financial Accounting Standard (IAS) 19 (revised 2010) on intangible assets is the adoption of International Accounting Standard (IAS) 38 on intangible assets (Ikatan Akuntan Indonesia, 2010). Within these standards, the IC is not mentioned explicitly, but the components of the IC (e.g., goodwill) described how the accounting treatment.

Bapepam-LK (2012) also issued a regulation on Submission of Annual Report of Public Company via the annual report, the company may present 'more' information of intangible assets. So, according to Guthrie dan Petty (2000) in particular, ICD can be a very effective means for companies to provide a signal of quality excellence because its importance of IC for future wealth creation. Espe-

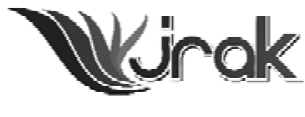

Jurnal Reviu Akuntansi dan Keuangan p-ISSN: $2615-2223$ e-ISSN: 2088-0685 Vol. 8 No. 1, April 2018 


\section{Islamic \\ Bank And \\ Sharia \\ Business...}

2 cially for companies with strong business IC, ICD can distinguish them from other low-quality companies (An et al., 2011).

The relationship between intellectual capital disclosure with the company's performance has been demonstrated by several investigators, one of them for example Milani dan Suwarni (2013) investigate on trends of intellectual capital disclosure in the banking industry. The study used 72 financial services company in banking sector listed in Indonesia Stock Exchange from 2009-2011. Results of the research showed that there is an increasing trend of intellectual capital disclosure, though not in its entirety.

Ramananda dan Nugrahanti (2014) also investigate on differences in the intellectual capital disclosure in 42 companies listed on the Indonesian Stock Exchange and 11 companies listed on the Thailand Stock Exchange (TSE) in 2011. The results showed that there is no differences in the level of intellectual capital disclosure between Indonesia and Thailand and that there are differences in the level of intellectual capital disclosure of companies based on profitability, leverage, and size.

Ulum (2011) Investigate on intellectual capital disclosure in the telecommunications company in Indonesia by using content analysis. From these studies showed that the percentage of IC disclosure items in annual reports telecommunication company in Indonesia is relatively high when compared with some of the findings in other countries. In 2007, there are still some IC attributes that are not disclosed at all by telecommunications companies, among others, patent, copyright, and trademark. In 2008, all the attributes of the IC has been disclosed by the company, just not all telecomucation companies disclose it. Six telecommunications companies that became the object of study, none of the companies disclose all the attributes intelllectual capital in its annual report. A maximum number of attributes disclosed is 24 .

Since the enactment of Act 21 of 2008 concerning Islamic Banking issued on July 16, 2008, the development of national Islamic banking industry increasingly have adequate legal base and will accelerate the faster growth again in the form of Islamic Banks (IB) and Syariah Business Unit (SBU). Throughout the year 2016 (per July) the development of Islamic banking has risen from the institutional side, the number of banks that conduct Islamic business increased along with the development and emergence of new players. Until the end of 2016, there is 165 Bank Rakyat Syariah Financing (BPRS). Number of service offices (Cash Office, Assistant Cash Office) until the end of 2016 reached 2,557 office networks throughout Indonesia (Financial Services Authority, 2016).

Based on these descriptions, this study will examine the differences of intellectual capital disclosure between Islamic Banks (IB) with Sharia Business Unit (SBU), the reason of researchers choses the banking company, because they are the company with more intensive knowledge and communication technologies, so that in carrying out its activities is more using IC compared with physical assets in a manufacturing company(Firer dan Williams, 2003). In this study, IC components used is ICD-In framework developed byUlum (2015) which consists of 36 items.

\section{METHOD}

This study is a comparative descriptive research, and population used is the Islamic Banking. While the sample is Islamic Bank and Sharia Business Units registered in Bank Indonesia in 2015. Sampling technique used in this research is purposive sampling, with the following criteria: 1) Islamic Banks and Sharia Business Unit which presents the annual report 2015; 2) Islamic Banks and Sharia Business Unit which publishes an annual report in 2015; 3) Islamic Banks and Sharia Business Unit for which data can be accessed. The data used is the data derived from the annual reports of Islamic Banks and Sharia Business Unit. While 
according to the source, the data used in this research is secondary data obtained using the documentation techniques.

Data analysis was performed with the following stages:

\section{Content Analysis}

This analysis is done by providing a checklist of the items IC disclosed in the annual report of each bank and business units. After the checklist, the next stage is done the sum of the items disclosed in each Islamic Bank and Sharia Business Unit. IC disclosure in the annual report is weighted in accordance with the projections using four-away numerical coding system developed by Guthrie et al. (1999). Numeric codes used are:

$0=$ item is not disclosed in the annual report

$1=$ item is dislcosed in narrative form

$2=$ item is dislosed in numerical form

$3=$ item is disclosed in monetary value

2. Test of mann-whitney

Test of Mann-Whitney is a non-parametric tests that were very strong and an alternative test of parametric test of t-test(Ghozali, 2006). Steps of mannWhitney test by comparing the number of items IC disclosed between Islamic Banks and Sharia Business Unit, starting from human capital, structural capital and relational capital.

\section{RESULTS AND DISCUSSION}

In this study, IC components used is ICD-In framework developed by Ulum (2015) which consists of 36 items. The first analysis conducted is content analysis. This analysis is used to identify the item of IC disclosed in the annual report of Islamic Banks and Sharia Business Unit by providing checklist on items disclosed in the annual report IB and SBU. The bases used to give a value of " 1 " if the item is disclosed in narrative form, a " 2 " if the item is disclosed in numerical form, the value of " 3 " if the item is disclosed with monetary value.

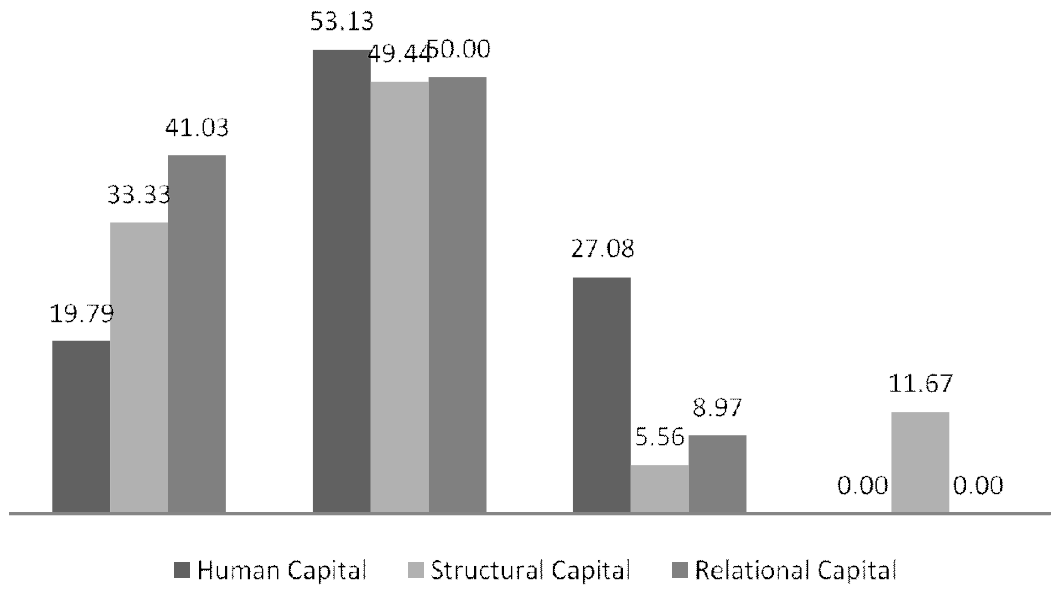

Figure 1.

Type of intellectual capital disclosure in Islamic Banks

Figure 1 presents information about how (media) selected by the Islamic Banks in presenting information on the IC. Information on human capital (HC) is more presented in a narrative format $(53.13 \%)$, then the number format $(27.08 \%)$, and the information that is not disclosed (19.79\%). None of the information about the $\mathrm{HC}$ which is presented in the form of currency. 
Islamic

Bank And

Sharia

Business...

4

Figure 2.

Type of intellectual capital disclosure in Sharia Business Unit
As well as information about the HC, information about the structural capital (SC) are also more disclosed in narrative format (49.44\%), then in the form of currency $(11.67 \%)$, in terms of numbers $(5.56 \%)$, and information that is not disclosed (33.33\%). The relatively similar proportions are also apparent from disclosing information about the relational capital (RC), where the type of information is more dominant narrative. However, the type of information that not disclosed was also quite dominant.

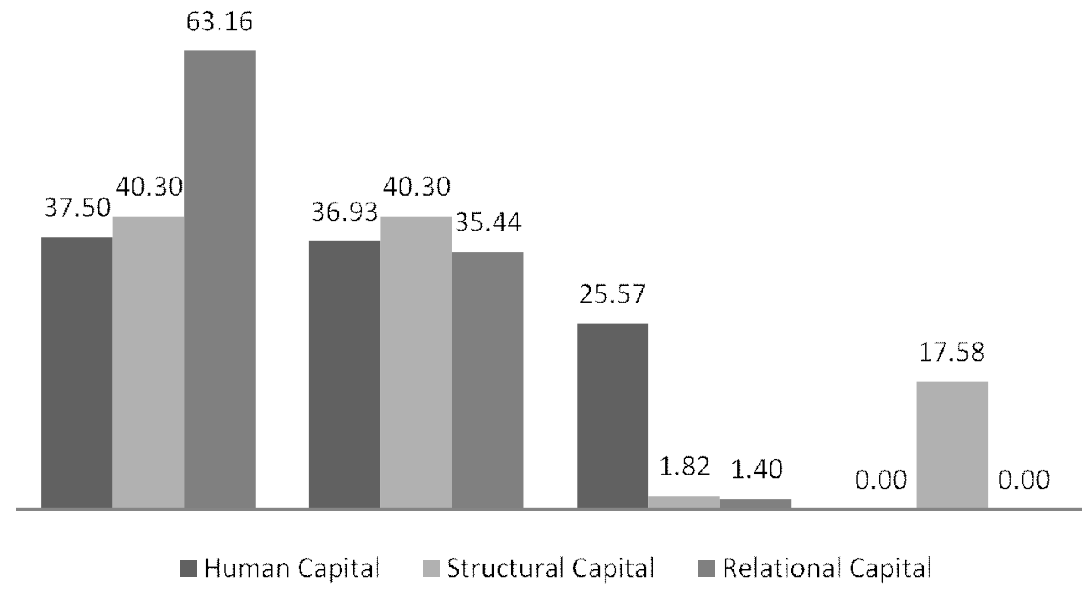

Figure 2 presents information about how (media) selected by the Sharia Business Unit in presenting information on the IC. It is different with Islamic Banks, in Sharia Business Unit, the percentage that does not disclose information about IC is very high. As shown in Figure 2, information about human capital (HC) is more presented in a narrative format $(36.93 \%)$, then the number format $(25.57 \%)$ and none of the information about the $\mathrm{HC}$ presented in the form of currency. But information that is not higher disclosed (37.50\%).

As well as information about the $\mathrm{HC}$, information about the structural capital (SC) are also more disclosed in narrative format (40.30\%), then in the form of currency $(17.58 \%)$, in terms of numbers $(1.82 \%)$, and information that is not disclosed in the SC is equal to the narrative format (40.30\%). The relatively similar proportions are also apparent from disclosing information about the relational capital (RC), where the type of information is more dominant narrative. However, the type of information that not disclosed was also quite dominant.

Based on the contents analysis, it can be seen that the IC disclosure on Islamic Banks is higher when compared with Sharia. However, 34 Islamic bankings, there are some attributes of the IC that are not disclosed at all by Islamic Bank and Sharia Business Unit, such as, patents, copyrights, and trademarks, so that none of the companies disclose all the attributes of intelllectual capital in its annual report. A maximum number of attributes disclosed is 31 . The results of this study are consistent with (Ulum, 2011; Milani and Suwarni, 2013) whose study stated that there is an increasing trend of intellectual capital disclosure, though not overall.

\begin{tabular}{llccc}
\hline \multicolumn{1}{c}{ Bank } & N & Mean Rank & Sum of Ranks \\
\hline \multirow{2}{*}{ ICD } & Islamic banking & 12 & 23,67 & 284,00 \\
& Sharia business Unit & 22 & 14,14 & 311,00 \\
& Total & 34 & & \\
\hline
\end{tabular}

Table 1 illustrates the average of IC disclosure on Islamic Banks in greater when compared with the Sharia Business Unit. This is evidenced by the average number of IC disclosure on Islamic Bank amounted to 23.67, while the average IC disclosure on Sharia Business Unit as much 14.14. 


\begin{tabular}{lr}
\hline & \multicolumn{1}{c}{ ICD } \\
\hline Mann-Whitney U & 58,500 \\
Wilcoxon W & 311,500 \\
Z & $-2,681$ \\
Asymp. Sig. (2-tailed) &, 007 \\
Exact Sig. [2*(1-tailed Sig.)] &, $007^{\mathrm{b}}$ \\
\hline
\end{tabular}

In this test, the Mann-Whitney test was used to compare the number of IC assessement between the IC of Islamic Bank and Sharia Business Unit. Based on table 4 is known that the value of $\mathrm{Z}$ count is -2.681. Asymp. Value is Sig. (2-tailed) in this study, that is 0,007 , so it can be said that the IC disclosure on Islamic Banks and Sharia Business Unit have a significant differences.

The results of this study are not consistent with Ramananda and Nugrahanti (2014) and (Ulum et al., 2016b) statet that the results of their research that there is a difference IC disclosure, but not too big. Because in previous studies, differences in the number of disclosures that occur on average only caused by disclosure form, it is in contrast with this study, where the difference are caused by differences in the level of disclosure. IC disclosure items in annual reports of Sharia Business Unit is relatively lower than Islamic Banks, because the annual report of Sharia Business Unit into one with annual reports of Conventional Bank. So much informations are not presented on the IC at the Sharia Business Unit itself. Interestingly, the number of items that are not disclosed by the Sharia Business Unit are the items that are mandatory of Bapepam-LK. For example, information about 'certification (item 34) is only disclosed by 4 of 22 Sharia Business Unit and information about 'marketing strategy' (item 35) is only disclosed by 8 of 22 Sharia Business Unit.

Submission of annual reports of public companies through the annual report has been stipulated in the regulations Bapepam-LK (2012) stated that through the annual report, the company can present 'more' information of intangible as' sets. In these regulations explicitly state that the company must provide information about the number of employees and description of competency development, for example, aspects of education and training of employees who have been made, this information is a reflection of aspects of human capital.

Whiting dan Miller (2008) explained that in the perspective of signaling theory, high-quality companies will tend to signal their superiority to the market. In contrast, companies with a capacity of not too good will be inclined to disclose information that is indeed mandatory. Furthermore, perspective of signaling theory, voluntary disclosure of IC information will be very effective medium for companies to deliver superior signal quality that they have related with ownership of significant IC to create the wealth in the future (Guthrie dan Petty, 2000; Whiting dan Miller, 2008).

Thus, the awareness of Islamic Banks and Sharia Business Unit for the importance of the publication and intellectual capital disclosure through voluntary annual report can be a very effective means for companies to provide a signal IC quality excellence because of its importance for future wealth creation. So it can be assumed that the more company manage its resources, it will be more producing a high performance of ICs and the number of IC disclosure in the annual report that could become more widespread.

Based on the description above indicates that the IC information disclosed by Islamic Banks is more than Sharia Business Unit. This is evidenced from the low disclosure of IC item on Sharia Business Unit due to annual reports of Sharia Business Unit into one with annual reports of Conventional Bank. So much information that is not presented on IC in Sharia Business Unit itself. Besides almost
Table 2 .

Statistics Test Results of MannWhitney 
Islamic

Bank And

Sharia

Business...

6 the entire IC items of UUS revealed only in narrative form so that a given value is only one, there is very little UUS revealed IC item in the form of monetary and scored three, so that the disclosure of the IC at a relatively low UUS. However, 34 Islamic bankings, there are some attributes of the IC that are not disclosed at all by Islamic Bank and Sharia Business Unit, such as, patents, copyrights, and trademarks, so that none of the companies disclose all the attributes of intelllectual capital in its annual report. A maximum number of attributes disclosed is 31 .

\section{CONCLUSION}

Based on the contents analysis can be concluded that the IC disclosure based on three categories: human capital, structural capital and relational capital, the highest IC disclosure is disclosed by Islamic Banks, Bank Jabar Banten Syariah by the number of judgment 31 or $86 \%$. There are 13 of 22 Sharia Business Units that disclosed IC e" $50 \%$ one of them by Permata Bank that the number of disclosure is 25 or $69.44 \%$.

Furthermore, after the test of Mann-Whitney on this study proves that there are significant differences between Islamic Banks and Sharia Business Unit, the differences are due to differences in the level of disclosure, the overall annual report Islamic Bank (IB) has already presented a disclosure of IC item, so that disclosure is relatively high when compared to Sharia Business Unit (SBU), because the annual report of SBU that joined with Conventional Bank. From 34 Islamic banking, there are some attributes of the IC that are not disclosed at all, such as patents, copyrights, and trademarks. A maximum number of attributes disclosed is 31 .

\section{LIMITATIONS AND SUGGESTIONS}

As usual, the research that uses content analysis, the researchers are difficult to avoid potential subjectivity when performing IC checklist item in the annual report. To minimize this subjectivity, further research should be done more than one person. It aims to reduce the subjectivity of researchers, because the method of the content analysis is very prone to subjectivity of the researchers themselves so that the results obtained will be less maximum.

Furthermore, this study only used data on the annual report regarding intellectual capital of Islamic banking to be used as research data. To get the more data accuracy, researchers can confirm to the banks, for example do an interview or questionnaire.

\section{DAFTAR PUSTAKA}

Bapepam-LK. 2012. Peraturan Nomor X.K.6 Lampiran Keputusan Ketua Bapepam dan LK Nomor: Kep-431/BL/2012 tentang Penyampaian Laporan Tahunan Emiten atau Perusahaan Publik Jakarta Bapepam-LK.

Firer, S., dan S. M. Williams. 2003. "Intellectual capital and traditional measures of corporate performance". Journal of intellectual capital.

Ghozali, I. 2006. "Statistik Non-Parametrik-Teori dan Aplikasi dengan Program SPSS". Universitas Diponegoro. Semarang.

Guthrie, J., dan R. Petty. 2000. "Intellectual capital: Australian annual reporting practices". Journal of Intellectual Capital.

Guthrie, J., R. Petty, F. Ferrier, dan R. Wells. 1999. "There Is No Accounting For Intellectual Capital In Australia: A Review Of Annual Reporting Practices And 
The Internal Measurement Of Intangibles”. Artikel dipresentasikan pada OECD Symposium on Measuring and Reporting of Intellectual Capital, di Amsterdam.

Ikatan Akuntan Indonesia. 2010. Pernyataan Standar Akuntansi Keuangan 19 (revisi 2010) tentang Aset Tak Berwujud.

Milani, E., dan E. Suwarni. 2013. "Tren Pengungkapan Intellectual Capital Industri Perbankan: Sebuah Bukti Empiris Di Indonesia”. Jurnal Keuangan dan Perbankan.

Nuswandari, C. 2009. "Pengungkapan Pelaporan Keuangan Dalam Perspektif Signalling Theory". Kajian Akuntansi.

Ramananda, D., dan Y. W. Nugrahanti. 2014. "Analisis Pengungkapan Intellectual Capital Berdasarkan Profitabilitas, Leverage, Dan Size Perusahaan (Perbandingan Antara Perusahaan Perbankan Di Indonesia Dan Thailand)”. Dinamika Akuntansi Keuangan dan Perbankan.

Ulum, I. 2011. "Analisis Praktek Pengungkapan Informasi Intellectual Capital dalam Laporan Tahunan Perusahaan Telekomunikasi di Indonesia". Jurnal Reviu Akuntansi dan Keuangan (JRAK).

—. 2015. Intellectual Capital: Model Pengukuran, Framework Pengungkapan, dan Kinerja Organisasi. Malang: UMM Press.

Ulum, I., T. F. A. Salim, dan E. T. Kurniawati. 2016a. "Pengaruh Corporate Governance Terhadap Praktik Pengungkapan Modal Intelektual Di Indonesia". Jurnal Dinamika Akuntansi dan Bisnis.

Ulum, I., A. Tenrisumpala, dan E. D. Wahyuni. 2016b. "Intellectual capital disclosure: studi komparasi antara universitas di Indonesia dan Malaysia". Akuntabilitas: Jurnal Ilmu Akuntansi.

Whiting, R. H., dan J. C. Miller. 2008. "Voluntary disclosure of intellectual capital in New Zealand annual reports and the "hidden value"'. Journal of Human Resource Costing \& Accounting.
JRAK 
